\title{
PENGARUH STRES KERJA TERHADAP PENINGKATAN TEKANAN DARAH PADA PEKERJA
}

\section{THE INFLUENCE OF WORK STRESS ON IMPROVING BLOOD PRESSURE ON WORKERS}

\author{
Indah Kurniasari, Sho'im Hidayat \\ Departemen Keselamatan dan Kesehatan Kerja \\ Fakultas Kesehatan Masyarakat, Universitas Airlangga \\ E-mail: indahkurniasari@live.com
}

\begin{abstract}
Work stress occurs when the demands of the job do not match with capabilities, resources, needs and worker discontent. One of the effects of work stress is increased blood pressure. This study was performed to determine the effect of work stress on the increased of blood pressure in press cutting PT. X. This study is analytical study which is explain the influence work stress to increase of blood pressure. This study using cross sectional methodology. The population of this study is people who work at press cutting PT. X who amount to 40 persons. The sampling technique is total sampling. In order to knowing the influence of work stress to increase of blood pressure that is using logistic regression and then that is explaining at narration and tables. The result of this study show that from 40 respondent $35.00 \%$ getting work stress. Respondent who get work stress and increased the blood pressure is $25.00 \%$ from 40 respondent. That is showing mean of blood pressure and increase blood pressure respondent's who get work stres higher than respondent who do not get work stress. Using logistic regression obtain $\operatorname{Exp}(B)=5.625$. It is showing at worker who get work stress have risk of increase blood pressure higher than do not get work stress.
\end{abstract}

Keywords: work stress, increase of blood pressure

\begin{abstract}
ABSTRAK
Stres kerja terjadi ketika tuntutan pekerjaan tidak sesuai dengan kemampuan, sumber daya, kebutuhan dan ketidakpuasan pekerja. Salah satu dampak stres kerja adalah meningkatnya tekanan darah pekerja. Penelitian ini dilakukan untuk mengetahui pengaruh stres kerja terhadap peningkatan tekanan darah pada pekerja bagian press cutting di PT. X. Penelitian ini merupakan penelitian analitik, yang menjelaskan pengaruh stres kerja terhadap peningkatan tekanan darah. Penelitian dilaksanakan dengan rancangan cross sectional. Populasi dalam penelitian ini adalah pekerja bagian press cutting di PT. X yang berjumlah 40 orang. Penarikan sampel dilakukan dengan cara total sampling. Untuk mengetahui ada atau tidaknya pengaruh stres kerja terhadap peningkatan tekanan darah maka dilakukan uji regresi logistik yang dianalisis dalam bentuk narasi dan tabel. Dari hasil penelitian didapatkan dari 40 responden $35,00 \%$ mengalami stres kerja. Pada responden yang mengalami stres kerja dan juga mengalami peningkatan tekanan darah didapatkan sebesar $25,00 \%$. Rata-rata tekanan darah dan peningkatan tekanan darah responden lebih tinggi pada kelompok yang mengalami stres kerja dari pada responden yang tidak mengalami stres kerja. Menggunakan uji regresi logistik diketahui nilai Exp $(B)=5,625$. Hal tersebut menunjukkan bahwa responden yang mengalami stres kerja berisiko untuk mengalami peningkatan tekanan darah 5,625 kali lebih tinggi dari pada yang tidak mengalami stres kerja.
\end{abstract}

Kata kunci: stres kerja, peningkatan tekanan darah

\section{PENDAHULUAN}

Stres merupakan ketegangan yang terjadi pada emosional, pemikiran dan kondisi fisik seseorang. Setiap individu memiliki potensi untuk mengalami stres. Tempat kerja merupakan salah satu tempat yang berisiko besar untuk menimbulkan stres. Stres merupakan salah satu bagian dari lingkungan kerja yang dapat membuat pekerja tetap termotivasi untuk giat bekerja. Stres yang berlebihan dapat menyebabkan pekerja mengalami gangguan kesehatan dan mengurangi produktivitas kerja, sehingga hal tersebut menjadi salah satu masalah utama bagi pekerja maupun perusahaan (Ismail, 2008).

Beberapa tahun terakhir diisukan bahwa stres memberikan pengaruh yang besar pada beberapa 
perusahaan di dunia industri. Sebuah yayasan promosi kesehatan di Australia mencatat bahwa stres kerja dialami oleh $25 \%$ pekerja wanita dan $18 \%$ oleh pekerja laki-laki. Prevalensi yang serupa juga tercatat oleh observasi di negara industri yang lain. Dampak akibat stres kerja tidak hanya terjadi pada individu karyawan tetapi juga pada organisasi atau perusahaan tempat bekerja. VicHealth (2012) mencatat bahwa $60 \%$ ketidakhadiran pekerja disebabkan oleh stres kerja, dan tingkat pergantian karyawan yang tinggi $40 \%$ disebabkan oleh stres kerja pada karyawan.

Masalah yang berkaitan dengan stres kerja juga terjadi di Indonesia. Sebuah penelitian di Universitas Diponegoro mencatat bahwa tingkat stres kerja karyawan bank BMT pada tahun 2012 adalah $48,6 \%$ dari 35 karyawan tidak mengalami stress, $48,6 \%$ dari 35 karyawan mengalami stres tingkat rendah dan $2,9 \%$ dari 35 karyawan mengalami stres tingkat tinggi (Fitri, 2013). Penelitian juga dilakukan Ismar (2011) pada pekerja call center menunjukkan bahwa dari 73 responden, $87,7 \%$ mengalami stres tingkat sedang-tinggi dan 12,3\% dari total responden mengalami stres tingkat rendah. Pada penelitian lain yang dilakukan oleh Hariyono, dkk (2009) pada perawat di sebuah rumah sakit di Yogyakarta menginformasikan bahwa dari total responden 52 orang 1,92\% mengalami stres ringan, $82,70 \%$ mengalami stres sedang dan $15,38 \%$ mengalami stres tinggi. Dari beberapa penelitian tersebut menunjukkan bahwa distribusi tingkat stres masih sangat bervariasi di perusahaan satu dengan yang lainnya.

Stres yang berasal dari tempat kerja sering disebut sebagai stres kerja, yang secara umum dapat dibedakan menjadi dua tipe yaitu eustress dan distress. Eustress didefinisikan sebagai stres ringan sampai stres sedang. Distress sering didefinisikan sebagai stres berat. Pekerja yang mengalami akan mampu beradaptasi terhadap tuntutan kerja dan pada beberapa orang akan membantu untuk meningkatkan performa kerja mereka. Sebaliknya, pada pekerja yang mengalami stres berat tidak akan mampu untuk memenuhi tuntutan kerja dan hal tersebut dapat mengurangi kualitas performa pekerja dalam bekerja (Ismail dkk, 2009).

Stres kerja dapat terjadi ketika tuntutan pekerjaan tidak sesuai dengan kemampuan, sumber daya, kebutuhan dan ketidakpuasan pekerja. Faktor pemicu stres kerja secara garis besar berasal dari dua faktor yaitu faktor yang berhubungan dengan organisasi dan individu. Faktor yang berhubungan dengan organisasi antara lain jenis lingkungan, jenis organisasi, dan jenis pekerjaan. Faktor yang berhubungan dengan individu antara lain: karakteristik individu dan kondisi kehidupan pribadi pekerja tersebut (Vokic, 2007). Health Advocate (2009) mencatat bahwa faktor penyebab stres kerja yang utama berdasarkan faktor organisasi antara lain $43 \%$ disebabkan karena beban kerja yang terlalu berat, $43 \%$ disebabkan oleh gaji yang diberikan kurang memadai, $43 \%$ karena kurangnya kesempatan untuk pengembangan karir, $40 \%$ disebabkan pekerjaan yang tidak realistik dan di luar harapan pekerja, dan 34\% dikarenakan jaminan keselamatan pekerjaan yang kurang.

Stres kerja menjadi topik yang popular dan penting dalam dunia kesehatan modern karena beberapa alasan, pertama stres memberikan efek yang berbahaya bagi fisik dan psikis pekerja, kedua stres merupakan penyebab utama ketidakhadiran pekerja, ketiga stres yang dialami oleh seorang pekerja akan memengaruhi keselamatan pekerja yang lain, keempat dengan mengontrol stres, individu dan perusahaan dapat mengatur pekerjaan secara efektif agar produktivitas tidak menurun (Beheshtifar, 2013).

Stres yang berlebihan dapat menimbulkan dampak fisik, psikis, dan perubahan sikap pada pekerja. Dampak fisik yang dapat timbul antara lain peningkatan tekanan darah, sakit kepala, migraine, gastritis, sakit punggung, asma, kelelahan, lesu, gangguan jantung, dermatitis, sakit pada otot dan perubahan pola makan, minum, tidur juga kebiasaan merokok (Vokic, 2007).

Dampak psikis yang dapat timbul antara lain pemendaman rasa cemas dan depresi, selalu menghindari pekerjaan, pemarah, ketegangan, gelisah, kekecewaan, dan perselisihan antar pegawai (Ismail dkk, 2009). Perubahan perilaku yang dapat timbul antara lain adalah perubahan kebiasaan untuk merokok, minum-minuman keras dan penggunaan obat-obatan terlarang, perubahan pola tidur dan pola makan (Tarwaka, 2013). Tidak hanya berdampak pada pekerja, stres kerja juga berdampak pada perusahaan. Dampak stres kerja pada perusahaan akan memberikan pengaruh yang kurang baik. Pengaruhnya dapat berupa tingginya angka tidak masuk kerja, turnover, hubungan kerja menjadi tegang dan rendahnya kualitas pekerjaan. Dari keadaan tersebut akan dapat mengganggu performansi kerja dan meningkatkan risiko terjadinya kecelakaan kerja. Terjadinya stres akibat kerja secara khusus akan dapat menurunkan produktivitas 
kerja dan menyebabkan biaya kompensasi pekerja meningkat (Tarwaka, 2013).

Peningkatan tekanan darah merupakan salah satu dampak fisik dari stres kerja yang perlu mendapatkan perhatian karena peningkatan tekanan darah yang terjadi secara terus menerus akan menyebabkan terjadinya darah tinggi pada pekerja. Peningkatan tekanan darah adalah meningkatnya tekanan darah di dalam arteri yang bisa terjadi akibat jantung memompa lebih kuat sehingga mengalirkan lebih banyak cairan pada setiap detiknya. Peningkatan tekanan darah ini dapat memengaruhi risiko terjadinya komplikasi apabila terjadi secara intermitten. Peningkatan tekanan darah dapat disebabkan oleh berbagai hal antara lain obesitas, konsumsi garam berlebih, konsumsi rokok dan alkohol, kurang olahraga serta stres. Salah satu faktor penting yang menyebabkan peningkatan tekanan darah adalah stres (Babba, 2007).

Peningkatan tekanan darah dapat menyebabkan gangguan jantung dan gangguan pembuluh darah. Selain itu darah tinggi menjadi berbahaya bukan hanya karena tekanan darah yang berlebihan saja, tapi karena penyakit lain yang ikut menyertainya. Penyakit tersebut dapat muncul atau diperparah dengan meningkatnya tekanan darah dalam tubuh kita. Penyakit yang dapat ditimbulkan oleh peningkatan tekanan darah antara lain atherosclerosis, gagal jantung, gangguan ginjal, disfungsi ereksi, gangguan penglihatan, gangguan daya pikir dan pikun (Poerwati, 2008).

Pengaruh stres kerja terhadap peningkatan tekanan darah diduga melalui aktivitas saraf simpatis yang dapat meningkatkan tekanan darah sebagai reaksi fisik bila seseorang mengalami ancaman secara intermitten. Stres yang berlangsung lama akan dapat mengakibatkan peninggian tekanan darah yang menetap. Saat keadaan stres, pembuluh darah akan menyempit sehingga menaikkan tekanan darah (Rahajeng dan Tuminah, 2009). Pengaruh stres kerja terhadap peningkatan tekanan darah juga masih kontroversi, sehingga perlu dilakukan penelitian untuk menambah kajian referensi mengenai tentang pengaruh stres kerja terhadap peningkatan tekanan darah.

Menurut Kadir (2013) pengaruh stres kerja terhadap peningkatan tekanan darah dapat dijelaskan dalam 3 fase perubahan yaitu perubahan hormon, respons fisik dan respons syaraf. Pada perubahan hormon yang terjadi adalah respons umum/general stres syndrome dikendalikan oleh hipotalamus, hipotalamus menerima masukan mengenai stressor fisik dan psikologis dari hampir semua daerah di otak dan dari banyak reseptor di seluruh tubuh. Sebagai respons hipotalamus secara langsung mengaktifkan sistem saraf simpatis. Mengeluarkan CRH untuk merangsang sekresi ACTH dan kortisol, dan memicu pengeluaran Vasopresin. Stimulasi simpatis pada gilirannya menyebabkan sekresi epinephrine, keduanya memiliki efek sekresi terhadap insulin dan glucagon oleh pancreas. Selain itu vasokontriksi arteriola di ginjal oleh katekolamin secara tidak langsung memicu sekresi renin dengan menurunkan aliran darah oksigen menurun ke ginjal. Renin kemudian mengaktifkan mekanisme rennin-angiotensin-aldosteron. Selama stres, hipotalamus mengintegrasikan berbagai respons baik dari sistem saraf simpatis maupun sistem endokrin. Pada respons fisik yang terjadi adalah tubuh dapat menunjukkan 3 tahap (fase) ketika menghadapi stres yaitu alarm stage, resistance stage, dan exhaustion stage. Pada alarm stage, terjadi peningkatan sekresi pada glandula adrenalis, mempersiapkan tubuh melaksanakan respons fight or fight. Seluruh efek tersebut menyebabkan orang tersebut dapat melaksanakan aktivitas fisik yang jauh lebih besar daripada bila tidak ada efek di atas. Pada resistance stage, terjadi setelah alarm stage. Selama fase ini tubuh memperbaiki dirinya sendiri akibat sekresi adrenokortikal yang menurun. Pada exhaustion stage sudah memengaruhi sistem organ, atau salah satu organ menjadi tidak berfungsi yang menyebabkan terjadinya stres yang kronis. Stres kronis ini dapat mengganggu fungsi otak, saraf otonom, sistem endokrin, dan sistem imun yang kita sebut sebagai penyakit psikosomatis. Pada respons syaraf yang terjadi adalah respons saraf utama terhadap rangsangan stres adalah pengaktifan menyeluruh sistem saraf simpatis. Hipotalamus akan menolong untuk mempersiapkan fight to flight akibat rangsangan stres. Hal ini menyebabkan peningkatan tekanan arteri, peningkatan aliran darah untuk mengaktifkan otot-otot, bersamaan dengan penurunan aliran darah ke organ-organ yang tidak diperlukan untuk aktivitas motorik yang cepat, peningkatan kecepatan metabolisme sel di seluruh tubuh, peningkatan konsentrasi glukosa darah, peningkatan proses glikolisis di hati dan otot, peningkatan kekuatan otot, peningkatan aktivitas mental, peningkatan kecepatan koagulasi darah PT. X merupakan sebuah perusahaan swasta yang memproduksi komponen-komponen dalam pembuatan knalpot. Proses produksi yang dilakukan dibagi menjadi 3 bagian, yaitu bagian shearing, 
press cutting, dan welding. Di PT. X terdapat 3 pembagian shift kerja yaitu shift 1 pada pukul 07.00 15.00, shift 2 pukul 15.00-23.00, serta shift 3 pukul 23.00-07.00. Hari operasional yang diberlakukan yaitu setiap Senin sampai Jumat. Pada penelitian ini akan dilakukan pembatasan pada pekerja di bagian press cutting, karena pada bagian shearing, press cutting, dan welding jenis pekerjaan yang dilakukan tidak sama, oleh karena itu pada penelitian ini hanya dilakukan pada bagian press cutting untuk mendapatkan beban kerja yang sama.

\section{METODE}

Penelitian ini merupakan penelitian analitik yang mencari pengaruh stres kerja terhadap peningkatan tekanan darah, dengan stres kerja sebagai variabel independen, peningkatan tekanan darah sebagai variabel dependen, dan karakteristik yang antara lain usia, jenis kelamin, tempat kerja, masa kerja, dan kebiasaan merokok sebagai variabel pengganggu. Rancangan penelitian adalah cross sectional dan bersifat observasional, peneliti tidak memberikan perlakuan terhadap obyek penelitian. Populasi dalam penelitian adalah pekerja bagian press cutting di PT. X yang berjumlah 40 orang. Penarikan sampel dilakukan dengan cara total sampling sehingga jumlah sampel didapatkan 40 orang.

Data yang digunakan adalah data primer, diambil dengan menggunakan kuesioner yang dibagikan kepada responden pada saat setelah bekerja, pengukuran tekanan darah dilakukan pada saat sebelum dan setelah bekerja. Kuesioner yang digunakan adalah kuesioner yang disadur dari buku Tarwaka (2013), sehingga dalam hal ini tidak dilakukan uji validitas dan uji reliabilitas.

Pengukuran tekanan darah dilakukan dengan menggunakan stetoskop dan sphygmomanometer jarum. Pengukuran dilakukan selama 2 hari dan dilakukan oleh 2 orang mahasiswa Fakultas Kesehatan Masyarakat Universitas Airlangga.

Dalam penelitian ini data akan dianalisis menggunakan tabel silang yang memuat data stres kerja dan tekanan darah. Untuk mengetahui pengaruh variabel stres kerja terhadap variabel peningkatan tekanan darah maka dilakukan uji regresi logistik, dan dilakukan analisis secara deskriptif. Untuk mengetahui ada atau tidaknya peranan variabel pengganggu maka dilakukan analisis secara deskriptif.

\section{HASIL}

\section{Gambaran Umum Perusahaan}

PT. X merupakan perusahaan yang bergerak di bidang industri komponen kendaraan bermotor yang memproduksi komponen knalpot kendaraan bermotor. Proses produksi dibagi menjadi 3 bagian, yaitu bagian shearing, press cutting, dan welding. Seluruh proses produksi tersebut berada pada 1 lokasi yang sudah terdapat mesin-mesin yang dioperasikan oleh seorang operator. PT. X beroperasi selama 24 jam mulai hari Senin-Jum'at, sehingga diberlakukan sistem kerja shift 1, 2 dan 3. Shift 1 dimulai pada pukul 07.00-15.00, shift 2 dimulai pukul 15.00-23.00, dan shift 3 dimulai pada pukul 23.00-07.00. Pengambilan data dilakukan di shift 1 .

\section{Karakteristik Responden}

Karakteristik responden adalah gambaran umum yang berkaitan dengan individu sebagai obyek penelitian yaitu pekerja pada bagian press cutting. Karakteristik dapat dibagi berdasarkan usia, jenis kelamin, tempat kerja, masa kerja dan kebiasaan merokok. Untuk jenis kelamin seluruh responden berjenis kelamin laki-laki, dan untuk tempat kerja seluruh responden bekerja di bagian press cutting PT. X. Untuk analisis usia, masa kerja dan kebiasaan merokok dianalisis pada Tabel 1 .

Karakteristik usia dapat diketahui bahwa hampir setengah responden berada pada kelompok usia $30-<40$ tahun yaitu sebesar $37,00 \%$ atau sebanyak 15 responden dari 40 responden, sebagian kecil responden berada pada kelompok usia $<20$ tahun dan $\geq 50$ tahun yaitu sebesar $7,50 \%$ dari 40 responden atau sebanyak 3 orang.

Untuk karakteristik masa kerja dapat diketahui bahwa hampir setengah dari responden memiliki masa kerja $>10$ tahun dengan persentase sebesar $47,50 \%$ dari 40 responden (19 responden) dan sebagian kecilnya memiliki masa kerja 5-10 tahun yaitu sebesar 12,50\% (5 responden).

Untuk karakteristik kebiasaan merokok dapat diketahui bahwa hampir seluruh responden memiliki kebiasaan merokok dengan persentase sebesar $77,50 \%$ (31 dari 40 responden). 
Tabel 1. Distribusi Karakteristik Responden pada Pekerja PT. X Bagian Press Cutting Mei 2104

\begin{tabular}{lcc}
\hline \multicolumn{1}{c}{ Karakteristik } & N & \% \\
\hline Usia & 3 & $7,50 \%$ \\
$<20$ tahun & 14 & $35,00 \%$ \\
$20-<30$ tahun & 15 & $37,50 \%$ \\
$30-<40$ tahun & 5 & $12,50 \%$ \\
$40-<50$ tahun & 3 & $7,50 \%$ \\
$\geq 50$ tahun & 40 & $100,00 \%$ \\
\hline Total & & \\
\hline Masa kerja & 16 & $40,00 \%$ \\
$<5$ tahun & 5 & $12,50 \%$ \\
$5-10$ tahun & 19 & $47,50 \%$ \\
$>10$ tahun & 40 & 100 \\
\hline Total & & \\
\hline Kebiasaan Merokok & 31 & $77,50 \%$ \\
Ya & 9 & $22,50 \%$ \\
Tidak & 40 & 100 \\
\hline Total & & \\
\hline
\end{tabular}

Tabel 2. Distribusi Stres dan Tingkat Stres Kerja pada Pekerja PT. X Bagian Press Cutting Mei 2014

\begin{tabular}{lcc}
\hline \multicolumn{1}{c}{ Kategori } & $\mathbf{n}$ & $\mathbf{\%}$ \\
\hline Stres Kerja & 14 & 35,00 \\
Tidak Stres Kerja & 26 & 65,00 \\
\hline Total & 40 & 100,00 \\
\hline Tingkat Stres Kerja & & \\
$\quad$ Ringan & 9 & 64,28 \\
$\quad$ Sedang & 5 & 35,72 \\
$\quad$ Berat & 0 & 0,00 \\
\hline Total & 14 & 100,00 \\
\hline
\end{tabular}

\section{Stres Kerja pada Pekerja Bagian Press Cutting}

Dari Tabel 2 didapatkan hasil pengukuran stres kerja adalah dari 40 responden di bagian press cutting sebagian besar responden tidak mengalami stres kerja yaitu sebanyak 65,00\% (26 responden). Untuk tingkat stres kerja dapat diketahui bahwa dari 14 responden yang mengalami stres kerja, sebagian besar responden mengalami stres kerja tingkat ringan dengan persentase $64,28 \%$ atau sebanyak 9 responden dan tidak ada satupun responden yang mengalami stres kerja tingkat berat.

Berdasarkan Tabel 3 dapat diketahui bahwa rata-rata usia responden yang mengalami stres kerja dan tidak stres kerja adalah sama yaitu 31 tahun. Untuk karakteristik masa kerja, dapat diketahui bahwa rata-rata masa kerja pada pekerja yang mengalami stres kerja dan tidak stres kerja berbeda 1 tahun, namun dari standar deviasi diketahui masa kerja pada responden yang mengalami stres kerja dan responden yang tidak mengalami stres kerja adalah sama.

Pada Tabel 4 dapat diketahui bahwa sebagian besar responden yang mengalami stres kerja dan tidak stres kerja sama memiliki kebiasaan merokok. Pada kelompok yang mengalami stres kerja rata-rata tekanan darah adalah 137,14 mmHg, pada kelompok yang tidak mengalami stres kerja rata-rata tekanan darah adalah $121,15 \mathrm{mmHg}$, rata-rata peningkatan tekanan darah pada kelompok stres kerja adalah $10,71 \mathrm{mmHg}$, sedangkan rata-rata peningkatan tekanan darah dari kelompok yang tidak stres kerja adalah $3,46 \mathrm{mmHg}$.

Hasil perhitungan dapat diketahui bahwa ratarata tekanan darah responden yang mengalami stres kerja lebih tinggi dari pada yang tidak mengalami stres kerja, juga dapat diketahui bahwa peningkatan tekanan darah pada kelompok yang mengalami stres kerja lebih tinggi. Pengaruh stres kerja terhadap

Tabel 3. Stres Kerja Berdasarkan Usia dan Masa Kerja Pekerja PT. X Bagian Press Cutting Mei 2014

\begin{tabular}{lccccc}
\hline \multicolumn{1}{c}{ Stres Kerja } & Mean & Std Deviation & Median & Minimum & Maximum \\
\hline Usia & & & & & \\
$\quad$ Tidak Stres Kerja & 31,62 & 10,288 & 32,50 & 19 & 51 \\
$\quad$ Stres Kerja & 31,07 & 11,816 & 32,50 & 19 & 58 \\
\hline Total & 31,43 & 10,698 & 32,50 & 19 & 58 \\
\hline Masa Kerja & & & & & \\
$\quad$ Tidak Stres Kerja & 9,50 & 7,783 & 10,00 & 1 & 25 \\
$\quad$ Stres Kerja & 8,79 & 7,127 & 7,00 & 1 & 20 \\
\hline Total & 9,25 & 7,476 & 8,00 & 1 & 25 \\
\hline
\end{tabular}


Tabel 4. Distribusi Stres Kerja Berdasarkan Kebiasaan Merokok pada Pekerja PT. X Bagian Press Cutting Mei 2014

\begin{tabular}{lrcrc}
\hline \multirow{2}{*}{$\begin{array}{l}\text { Kebiasaan } \\
\text { Merokok }\end{array}$} & \multicolumn{2}{c}{ Stres Kerja } & \multicolumn{2}{c}{$\begin{array}{c}\text { Tidak Stres } \\
\text { Kerja }\end{array}$} \\
\cline { 2 - 5 } & $\mathbf{n}$ & $\mathbf{\%}$ & \multicolumn{1}{c}{ n } & $\%$ \\
\hline Merokok & 12 & 85,71 & 20 & 76,92 \\
Tidak Merokok & 2 & 14,29 & 6 & 23,08 \\
\hline Total & 14 & 100,00 & 26 & 100,00 \\
\hline
\end{tabular}

Tabel 5. Stres Kerja terhadap Peningkatan Tekanan Darah Sistolik Responden pada Pekerja PT. X Bagian Press Cutting Mei 2014

\begin{tabular}{lcc}
\hline \multirow{1}{*}{ Statistik } & \multicolumn{2}{c}{ Tekanan } \\
\cline { 2 - 3 } & Stres Kerja & $\begin{array}{c}\text { Tidak Stres } \\
\text { Kerja }\end{array}$ \\
\hline Mean & $137,14 \pm 9,139$ & $121,15 \pm 8,638$ \\
Median & 135 & 120 \\
Minimum & 130 & 100 \\
Maksimum & 160 & 140 \\
Rata-rata Peningkatan & $10,71 \pm 7,30$ & $3,46 \pm 5,616$ \\
\hline Jumlah Responden & 14 & 26 \\
\hline
\end{tabular}

peningkatan tekanan darah pekerja bagian press cutting.

Berdasarkan Tabel 6 dapat diketahui bahwa terdapat 4 kelompok, yaitu kelompok pertama adalah responden yang mengalami stres kerja dan tekanan darah yang meningkat, kelompok kedua adalah responden yang mengalami peningkatan tekanan darah dan tekanan darah tidak meningkat, kelompok ketiga adalah responden yang tidak mengalami stres kerja dan tekanan darah meningkat, kelompok keempat adalah responden yang tidak mengalami stres kerja dan tekanan darahnya tidak meningkat.

Persentase terbesar terdapat pada kelompok keempat yaitu responden yang tidak mengalami stres kerja dan tekanan darah yang tidak meningkat dengan persentase sebesar $45,00 \%$. Persentase terkecil adalah pada kelompok kedua yaitu responden yang mengalami stres kerja dengan tekanan darah yang tidak meningkat dengan persentase sebesar $10,00 \%$.

\section{PEMBAHASAN \\ Karakteristik}

Hasil penelitian diketahui bahwa karakteristik responden antara lain usia, jenis kelamin, tempat kerja, masa kerja dan kebiasaan merokok adalah sama antara responden yang mengalami stres kerja dan responden yang tidak mengalami stres kerja, sehingga dalam hal ini karakteristik tidak memberikan pengaruh terhadap pengaruh stres kerja terhadap peningkatan tekanan darah.

\section{Stres Kerja pada Pekerja Bagian Press Cutting}

Pada bagian press cutting terdapat 40 pekerja yang bersedia menjadi responden dalam penelitian ini dan mengikuti rangkaian penelitian secara keseluruhan. Dari hasil penelitian terdapat responden yang mengalami stres kerja yaitu sebesar $35,00 \%$ dari 40 responden, sedangkan yang tidak mengalami stres kerja adalah sebesar 65,00\%. Karakteristik antara lain usia, jenis kelamin, tempat kerja, masa kerja dan kebiasaan merokok pada responden yang mengalami stres kerja dan pada responden yang tidak stres kerja adalah sama, sehingga dalam hal ini karakteristik tidak menjadi variabel pengganggu.

Menurut Stranks (2005) dalam Poerwati (2008) salah satu faktor penyebab stres kerja adalah faktor lingkungan fisik yang antara lain adalah tata ruang yang tidak ergonomis, ruang yang tidak nyaman dan tidak efisien, suhu dan kelembapan yang tidak baik, penerangan yang kurang, kebisingan yang berlebihan, ventilasi yang tidak baik. Menurut Wahjono (2010) sumber stres berasal dari 3 faktor yang salah satunya adalah faktor organisasi yaitu

Tabel 6. Pengaruh Stres Kerja terhadap Peningkatan Tekanan Darah Responden pada Pekerja PT. X Bagian Press Cutting Mei 2014

\begin{tabular}{|c|c|c|c|c|c|c|}
\hline \multirow{3}{*}{ Stres Kerja } & \multicolumn{4}{|c|}{ Tekanan Darah } & \multirow{2}{*}{\multicolumn{2}{|c|}{ Total }} \\
\hline & \multicolumn{2}{|c|}{ Meningkat } & \multicolumn{2}{|c|}{ Tidak Meningkat } & & \\
\hline & $\mathbf{n}$ & $\%$ & $\mathbf{n}$ & $\%$ & $\mathbf{N}$ & $\%$ \\
\hline Stres Kerja & 10 & 25,00 & 4 & 10,00 & 14 & 35,00 \\
\hline Tidak Stres Kerja & 8 & 20,00 & 18 & 45,00 & 26 & 65,00 \\
\hline Total & 18 & 100,00 & 22 & 100,00 & 40 & 100,00 \\
\hline
\end{tabular}


tuntutan tugas, tuntutan peran dalam organisasi, tuntutan antar-pribadi, struktur organisasi dan kepemimpinan organisasi. Dalam VicHealth (2012) salah satu sumber stres kerja berasal dari keadaan fisik dan psikis, keadaan fisik dapat berupa umur, jenis kelamin, dan status kesehatan sedangkan keadaan psikis dapat berupa kepribadian dan kemampuan mengatasi masalah. Pada bagian press cutting, stres kerja dapat muncul akibat paparan dari faktor lingkungan kerja (kebisingan, suhu, pencahayaan dan hygiene), paparan faktor organisasi (beban kerja, shift kerja, hubungan antar pekerja, hubungan antara pekerja dengan atasan, struktur dan iklim organisasi) dan faktor individu (usia, masa kerja, dan kepribadian).

Paparan faktor fisik seperti kebisingan pada bagian press cutting merupakan kebisingan yang terjadi secara terus menerus atau kebisingan kontinyu. Kebisingan dapat mengganggu keadaan fisik dan psikologis pekerja dan apabila terjadi secara terus menerus akan menyebabkan munculnya stres kerja. Begitu pula dengan paparan yang berasal dari pencahayaan. Pencahayaan yang kurang dapat mengakibatkan gangguan fisik dan psikologis pada saat proses bekerja. Suhu juga dapat memengaruhi keadaan fisik dan psikologi pekerja, suhu yang tidak sesuai akan menyebabkan tubuh beradaptasi dengan suhu lingkungan, apabila tubuh tidak dapat beradaptasi akan menyebabkan stres kerja.

Pada paparan faktor organisasi dapat berasal dari hubungan antar pekerja dan hubungan pekerja dengan atasan bila terjadi ketidaksesuaian pada hubungan tersebut dapat menyebabkan gangguan secara psikologis.

Paparan yang berasal dari faktor individu merupakan faktor yang sulit untuk dibatasi, karena faktor individu merupakan faktor yang mutlak bawaan dari individu masing-masing pekerja, sehingga untuk mengurangi paparan yang berasal dari faktor individu harus ada perubahan dari kepribadian atau kemampuan mengatasi masalah pekerja.

Akibat adanya paparan dari faktor lingkungan kerja, faktor organisasi maupun faktor individu dapat mengakibatkan rangsangan pada sistem syaraf, ketidakstabilan emosi mengakibatkan seseorang mudah mengalami stres. Munculnya respons dari gangguan fisik maupun psikologis yang berupa kondisi ketegangan pekerja akibat rangsangan sistem syaraf yang tidak mampu diterima pekerja tersebut merupakan stres kerja yang dapat menimbulkan efek atau dampak pada perusahaan maupun pada pekerja.

Dalam VicHealth (2012), stres kerja dapat berdampak pada kesehatan pekerja dan perusahaan. Dampak stres kerja terhadap kesehatan adalah munculnya masalah kesehatan fisik (serangan jantung, CVD, CHD, hipertensi, diabetes, dan gangguan metabolisme), kesehatan psikis (depresi, kecemasan yang berlebihan, bunuh diri, muram, kesehatan mental menurun), dampak perilaku (kebiasaan merokok, pecandu alkohol, aktivitas berkurang, pola makan yang tidak teratur, obesitas). Dampak pada perusahaan antara lain meningkatkan angka pergantian pekerja, peningkatan ketidakhadiran pekerja karena sakit dan prestasi kerja yang menurun karena sakit sehingga hal tersebut dapat mengurangi produktivitas kerja, meningkatkan kecelakaan kerja sehingga meningkatkan pengeluaran perusahaan untuk biaya kesehatan dan kompensasi untuk pekerja. Terdapat beberapa responden yang memiliki kebiasaan merokok dan juga terdapat beberapa responden yang mengalami hipertensi.

\section{Tekanan Darah Pekerja Bagian Press Cutting}

Dari hasil pengukuran tekanan darah didapatkan rata-rata tekanan darah pada responden yang mengalami stres kerja lebih tinggi dari pada ratarata tekanan darah responden yang tidak mengalami stres kerja. Begitu pula pada rata-rata peningkatan tekanan darah sebelum dan setelah bekerja, pada responden yang mengalami stres kerja rata-rata peningkatan tekanan darah lebih tinggi dari pada yang tidak mengalami stres kerja.

Menurut WHO (2013) terdapat beberapa faktor yang memengaruhi peningkatan tekanan darah, antara lain faktor perilaku, faktor metabolisme tubuh, faktor sosial ekonomi dan faktor lainnya. Menurut Poerwati (2008) faktor yang memengaruhi peningkatan tekanan darah adalah faktor yang dapat dihindari (obesitas, konsumsi garam berlebih, konsumsi rokok, konsumsi alkohol, stres dan kurang olah raga) dan faktor yang tidak dapat dihindari (faktor genetik, umur, dan jenis kelamin).

Pada pekerja bagian press cutting peningkatan tekanan darah dapat terjadi karena faktor perilaku, faktor metabolisme tubuh, faktor sosial ekonomi, dan faktor lainnya. Menurut WHO (2013) faktor perilaku yang antara lain konsumsi makanan yang terlalu banyak mengandung garam dan lemak, kurang konsumsi buah dan sayur, konsumsi alkohol dan rokok, kurang olahraga, dan kurang 
stress management, merupakan faktor terbesar yang memengaruhi tekanan darah seseorang. Tekanan darah pekerja dapat meningkat saat setelah bekerja karena stres kerja, beban kerja dan kondisi lingkungan kerja yang dapat menimbulkan peningkatan aktivitas kerja jantung sehingga jantung memompa darah lebih keras untuk memberikan aliran darah pada seluruh tubuh.

Peningkatan tekanan darah ini dapat memberikan dampak yang serius pada kesehatan. Menurut Poerwati (2008), dampak tersebut antara lain adalah hipertensi menetap, sakit kepala bagian belakang dan kaku kuduk, sulit tidur dan gelisah atau cemas, kepala pusing, dada berdebar-debar, lemas, sesak nafas, berkeringat, mata berkunangkunang, dan menurut Kowalski (2010) peningkatan tekanan darah dapat meningkatkan risiko terjadinya stroke dan risiko penyakit jantung. Pada responden yang mengalami peningkatan tekanan darah, apabila tekanan darah terjadi secara terus-menerus dan intermitten akan menyebabkan hipertensi yang menetap. Selain meningkatkan risiko terjadinya hipertensi yang menetap, dampak lain akibat peningkatan tekanan darah juga harus diwaspadai terutama munculnya penyakit yang mematikan seperti serangan jantung yang bisa terjadi sewaktuwaktu.

\section{Pengaruh Stres kerja terhadap Peningkatan Tekanan Darah Pekerja Bagian Press Cutting}

Berdasarkan analisis regresi logistik diperoleh nilai $\operatorname{Exp}(\mathrm{B})=5,625$ yang berarti risiko peningkatan tekanan darah pada responden yang mengalami stres kerja adalah 5,625 kali dari pada responden yang tidak mengalami stres kerja khususnya pada pekerja PT. X bagian press cutting.

Pada kelompok yang mengalami stres kerja memiliki rata-rata tekanan darah yang lebih tinggi dari pada kelompok yang tidak mengalami stres kerja. Sehingga dapat diketahui bahwa stres kerja memang memberikan pengaruh pada peningkatan tekanan darah pada penelitian ini.

Dalam uji statistik dapat disimpulkan pekerja yang mengalami stres kerja berisiko lebih besar untuk mengalami peningkatan tekanan darah. Hal ini dapat disebabkan akibat pekerja yang mengalami paparan dari lingkungan kerja dapat merangsang syaraf pekerja yang mengakibatkan ketegangan pada syaraf sehingga pekerja akan mengalami stres kerja. Seperti yang telah dijelaskan sebelumnya bahwa stres kerja dapat memberikan dampak pada pekerja.
Salah satu dampak yang dapat dialami pekerja adalah meningkatnya tekanan darah. Hal ini dikarenakan pada saat pekerja mengalami ketegangan syaraf dan stres kerja akan mengakibatkan jantung memompa darah lebih kuat, dan tubuh akan bereaksi dengan meningkatkan pengeluaran hormon khususnya hormon catecholamines dan corticosteroid (Poerwati, 2008). Akibat stres kerja jantung yang memompa darah lebih kuat menyebabkan tekanan pada pembuluh darah akan meningkat, karena volume darah yang dipompa juga akan lebih banyak. Apabila peningkatan tekanan darah terjadi secara terus menerus maka hal ini dapat menyebabkan hipertensi menetap dan gangguan jantung pada pekerja.

Menurut Kadir (2013) respons saraf utama terhadap rangsangan stres adalah pengaktifan menyeluruh sistem saraf simpatis, hipotalamus akan menolong untuk mempersiapkan fight or flight akibat rangsangan stres, hal tersebut akan menyebabkan peningkatan tekanan arteri dan peningkatan aliran darah untuk mengaktifkan otot-otot, akibat aliran darah yang meningkat maka tekanan darah pun akan meningkat.

Dalam jurnal yang disusun oleh Zimmerman dan Frohlich (1990) menyimpulkan bahwa stres kerja yang berkepanjangan dan berulang-ulang pada pekerja dapat menyebabkan peningkatan tekanan darah yang irreversibel, dan peningkatan tekanan darah yang terus-menerus dan intermitten akan menyebabkan hipertensi yang menetap.

Pada penelitian ini dapat ditemukan beberapa responden yang mengalami stres kerja dan juga mengalami peningkatan tekanan darah, yaitu sebesar $25,00 \%$ dari 40 responden, dibandingkan dengan responden yang tidak mengalami stres kerja dan mengalami peningkatan tekanan darah yaitu sebesar 20,00\% dari 40 responden. Stres kerja memberikan pengaruh terhadap peningkatan tekanan darah responden.

Untuk mengetahui adanya pengaruh stres kerja terhadap peningkatan tekanan darah, oleh karena itu perlunya dilakukan program manajemen stres kerja yaitu dilakukan identifikasi penyebab stres, penilaian dan pengendalian risiko terjadinya stres di setiap perusahaan. Hal tersebut dapat meminimalkan terjadinya stres kerja, hipertensi dan penyakit lain akibat stres kerja, selain itu dengan dilakukannya manajemen stres kerja pada perusahaan akan mengurangi kerugian akibat stres kerja yang timbul pada perusahaan. 


\section{SIMPULAN}

Karakteristik responden antara lain usia, jenis kelamin, tempat kerja, masa kerja, dan kebiasaan merokok tidak memiliki perbedaan antara responden yang mengalami stres kerja dan yang tidak mengalami stres kerja. $35,00 \%$ dari 40 responden mengalami stres kerja.

Tekanan darah responden yang mengalami stres kerja lebih tinggi dari pada tekanan darah responden yang tidak mengalami stres kerja. Begitu juga peningkatan tekanan darah responden yang mengalami stres kerja lebih tinggi dari pada yang tidak mengalami stres kerja. Pekerja yang mengalami stres kerja berisiko 5,625 kali lebih tinggi mengalami peningkatan tekanan darah dari pada pekerja yang tidak mengalami stres kerja.

\section{DAFTAR PUSTAKA}

Babba, J. 2007. Hubungan antara Intensitas Kebisingan di Lingkungan Kerja dengan Peningkatan Tekanan Darah. Tesis. Program Pasca Sarjana Magister Kesehatan Lingkungan. Semarang: Universitas Diponegoro.

Beheshtifar, M., Nazarian, R. 2013. Role of Occupational Stress in Organizations. IJCRB, Vol. 4, No. 9.

Fitri, A.M. 2013. Analisis Faktor-Faktor yang Berhubungan dengan Kejadian Stres Kerja pada Karyawan Bank. Jurnal Kesehatan Masyarakat FKM UNDIP, Vol. 2, No. 1.

Hariyono, W., Suryani, D., Wulandari, Y. 2009. Hubungan antara Beban Kerja, Stres Kerja dan Tingkat Konflik dengan Kelelahan Kerja Perawat. Jurnal KES MAS UAD, Vol. 3, No. 3.

Health Advocate. 2009. Stress in The Workplace Meeting The Challenge. Health Advocate, Inc.

Ismail, A., Yao, A., Yunus, N.K.Y. 2009. Relationship between Occupational Stress and Job Satisfaction: an Empirical Study in Malaysia. The Romanian Economic Journal, Vol. 12, No. 34.

Ismail, R. 2008. Occupational Stress and Personality Characteristic. Journal of Community Health 2008, Vol. 14, No. 2.

Ismar, R., Amri, Z., Sostrosumihardjo, D. 2011. Stres Kerja dan Berbagai Faktor yang Berhubungan pada Pekerja Call Center. Artikel Penelitian Kedokteran Indonesia, Vol. 61, No. 1.

Kadir, A. 2013. Perubahan Hormon terhadap Stres. Fakultas Kedokteran Universitas Wijaya Kusuma Surabaya.

Kowalski, R.E. 2010. The Blood Pressure Cure: 8 Weeks to Lower Blood Pressure. WILLEY.

Poerwati, R. 2008. Hubungan Stres Kerja terhadap Hipertensi pada Pegawai Dinas Kesehatan Kota Pekan Baru Tahun 2008. Tesis. Universitas Sumatera Utara.

Rahajeng, E., Tuminah, S. 2009. Prevalensi Hipertensi dan Determinannya di Indonesia. Artikel Penelitian, Majalah Kedokteran Indonesia, Vol. 59, No. 12.

Tarwaka. 2013. Ergonomi Industri/Dasar-Dasar Pengetahuan Ergonomi dan Aplikasi di Tempat Kerja. Surakarta: Harapan Press.

Wahjono, S.I. 2010. Perilaku Organisasi. Yogyakarta: Graha Ilmu.

World Health Organization (WHO). 2013. A Global Brief on Hypertension, Silent Killer, Global Public Health Crisis.

VicHealth. 2012. Reducing Stress in the Workplace (An Evidence Review: Summary Report). Melbourne: Victorian Health Promotion Foundation.

Vokic, N.P. 2007. Individual Differences and Occupational Stress Perceived. Working Paper Series, Paper No. 07-05.

Zimmerman, R.S., Frohlich, E.D. 1990. Stress and Hypertention. Journal of Hypertension 1990. 8 (suppl 4): S103-107. 